\title{
The Uncertain Renaissance of the Ninth Amendment $\dagger$
}

Legal commentators who advocate increased protection of individual rights by the Supreme Court have long chafed under the restrictions imposed by the specificity of the first eight amendments. One has suggested that unenumerated rights which can be classified as fundamental or inherent should be protected by the ninth amendment ${ }^{3}$ "without the necessity of including them within the protection of the due process clause of the Fourteenth Amendment."2 Another commentator has argued simply that the ninth amendment protects all those rights which "a free society reserves to the people" and that "accordingly, the Ninth and Tenth Amendments should be used to define rights adjacent to, or analogous to, the pattern of rights which we find in the Constitution."3 Both viewpoints assume that the ninth is a fountainhead of unarticulated rights. Many, such as Mr. Justice Jackson, remain uncertain: "[T] $]$ he ninth amendment rights which are not to be disturbed by the federal government are still a mystery to me."'4

This mystery was largely academic until Mr. Justice Goldberg's concurring opinion in Griswold $\%$. Connecticut ${ }^{5}$ accorded the ninth exten-

† James F. Kelley, J.D. 1966, The University of Chicago Law School.

1 The ninth amendment reads: "The enumeration in the Constitution, of certain rights, shall not be construed to deny or disparage others retained by the people."

2 Patterson, The Forgotten Ninth AMEndment 45 (1955). Aside from Patterson, the bibliography of the ninth amendment seems to be limited to the following: Call, Federalism and the Ninth Amendment, 64 Drck, L. REv. 121 (1960); Dunbar, James Madison and the Ninth Amendment, 42 VA. L. REv. 627 (1956); Kelsey, The Ninth Amendment, 11 Ind. L.J. 309 (1936); Redlich, Are There "Certain Rights . . Retained by the People"?, 37 N.Y.U.L. REv. 787 (1962); Rogge, Unenumerated Rights, 47 CALIF. L. REv. 787 (1959).

3 Redlich, supra note 2, at 812.

1 Jackson, The Supreme Court in the American System of Government $74-75$ (1955).

5381 U.S. 479 (1965). The previous Supreme Court cases interpreting the ninth amendment are Roth v. United States, 354 U.S. 476 (1957); United Public Workers v. Mitchell, 330 U.S. 75 (1947); Tennessee Elec. Power Co. v. Tennessee Valley Authority, 306 U.S. 118 (1939); Ashwander v. Tennessee Valley Authority, 297 U.S. 288 (1936). See discussion at text accompanying notes $48-76$ infra.

The decision in Griswold prompted a good deal of scholarly activity. See Franklin, The Ninth Amendment, 40 Tur. L. REv. 487 (1966); Kelly, Glio and the Court: An Illicit Love Affair, 1965 Sup. Cr. Rev. 119, 149-55. See also Comment, The Ninth Amendment, 30 ALbANy L. REv. 89 (1966); Note, The Ninth Amendment, 11 S.D.L. Rev. 172 (1966); The 
sive analysis and stirred wide interest in those rights "retained by the people." At the risk of muddying further a stream of constitutional law better left in tranquility, this comment examines the history of the enactment of the ninth amendment and explores its possible meanings. The results of this examination strongly suggest that the ninth amendment is only a rule of construction applicable to the entire Constitution; it is a guidepost at the end of the Bill of Rights reminding courts of the existence of other rights not specifically enumerated. It is emphatically not the source of these rights, nor is it a vehicle for protecting them. Rather, it points to other parts of the Constitution - particularly the due process clauses of the fifth and fourteenth amendments-as the contexts within which unenumerated rights are to be determined, and the means by which they are to be protected.

\section{An Historical Background}

When the delegates to the Constitutional Convention met in Philadelphia in the spring of 1787, few of them believed that a bill of rights should be included in the new Constitution. The framers were not hostile to individual rights; rather, they were heavily influenced by the prevailing political theory in the United States. At the time the Constitution was drafted, nearly every political leader in the country was a disciple of the natural law school, ${ }^{6}$ first expounded in John Locke's Of Civil Government and embodied in the colonies in such documents as the Virginia Declaration of Rights ${ }^{7}$ and the Declaration of Independence.

Supreme Court, 1964 Term, 79 HARv. L. REv. 56, 162-65 (1965). Student case notes on Griswold include 7 ARIz. L. Rev. 252 (1966); 32 BROOKLYN L. REV. 172 (1965); 69 Dick. L. REv. 417 (1965); 37 Miss. L.J. 304 (1966); 40 TuL. L. REv. 418 (1966); 35 U. CiNc. L. REv. 134 (1966); 38 U. Colo. L. Rev. 267 (1966); 34 U. Mo. Kan. City L. Rev. 95 (1966); 17 SYracuse L. REv. 553 (1965); 18 VAND. L. Rev. 2037 (1965); 12 WAYNe L. Rev. 479 (1966); 17 W. Res. L. REv. 601 (1966); 5 WASHBURN L.J. 286 (1966).

Several of the above notes have also discussed the right of privacy, an aspect of which Griswold is thought to have protected. See also Symposia-The Right of Privacy and Griswold $v$. Connecticut, 64 MICF. L. REv. 124 (1965); authorities cited note 61 infra.

6 Natural law comprised a set "of ideas that compelled the allegiance of every politically minded American." Rossrter, 1787: The GrANd Conventron 60 (1966). It is beyond the scope of this comment to undertake a thorough examination of natural law philosophy and political theory; its outlines are developed here only to aid the discussion of the ninth amendment. For further discussion of these topics, see, e.g., Rossrter, SEEDtIMTE OF THE REPUBLIC (1953); WRIGHT, AMIERICAN INTERPRETATIONS OF NATURAL LAW (1962); Corwin, The "Higher Law" Background of American Constitutional Law (pts. 1, 2), 42 HARv. L. REv. 149, 365 (1928).

$\tau$ The Virginia Declaration of Rights, contained in that state's constitution of 1776, is generally considered the first state bill of rights. It is reprinted in 8 THORPE, THE FEDERAL AND STATE CoNstitutions 3812 (1909). 
At the core of this political philosophy was the belief that the political and social rights of men flowed from a series of laws limiting the reach of established political authority, that these rights were inalienable and essential to human existence, and that they could not be affected by governmental action. Although men might surrender some of their rights in exchange for the benefits of a general government, their inalienable rights, such as freedom of speech, liberty of the press, and trial by jury, could not be given up and were not subject to constraint by the political authority which men established.

Imbued with these ideas the framers met to draft the Constitution. Since each of the states already had a constitution, the distribution of governmental authority and individual rights had been clearly established. The formation of the féderal government would in no way affect this configuration, since the states would merely delegate some of their governmental power to the new government in exchange for the benefits that were expected from a central government. The delegates, therefore, gave scant attention to a bill of rights. The discussion elicited during the one attempt that was made to include a bill of rights clearly revealed the prevailing attitude: the state constitutions and declarations of rights would not be repealed by the new Constitution and would continue to protect these rights. ${ }^{8}$

However, despite the theoretical justification for the absence of a bill of rights, that absence was inconsistent with another cardinal tenet of the philosophy of the time, and with other parts of the Constitution itself. One of the main principles inherited from English constitutional law was that constitutionalism "calls for inclusion in the constitution of a specific declaration of natural and civil rights." This principle apparently derived from the Magna Carta itself: "Magna Carta stood for the notion that the expression of the will of the people about the fundamental rights that were retained by them was to be itemized in a written document."10

The requirement of codifying fundamental rights might have been ignored in the case of the Constitution, since the power of the federal government was to affect only state governments. But various clauses of the Constitution did specifically provide for the protection of certain

82 Farrand, The Records of the Federal Convention 587-88 (rev. ed. 1937). See also note 10 infra.

9 Rossiter, 1787: The Grand Convention 64 (1966).

10 Kurland, Magna Carta and Constitutionalism in the United States: "The Noble Lie," in The Great Charter 58 (1965). In spite of this fact, several states did not have bills of rights at the time the Constitution was written: Connecticut, Georgia, New Hampshire, New Jersey, New York, and South Carolina. Wright, AmERICAN INTERPRETATIONs of NATURAL LAW 112-14 (1962). 
rights that might properly be considered part of the subject matter of a bill of rights. Among these were the prohibitions of suspension of habeas corpus, ${ }^{11}$ bills of attainder and ex post facto laws; ${ }^{12}$ the guarantee of trial by jury; ${ }^{13}$ and the provision that treason could be proved only on the testimony of two witnesses or on confession in open court. ${ }^{14}$ The enumeration of these protected rights in the Constitution made it difficult to sustain the argument that the Constitution affected only the allocation of governmental power between the states and the federal authority. ${ }^{15}$

To the surprise of most of the framers, the omission of a bill of rights proved to be the greatest single obstacle to ratification of the Constitution. Both Federalists and Antifederalists ${ }^{16}$ objected to its absence, although the Federalists, intent on securing adoption, attempted to explain away this defect by arguing that the Constitution in no way affected the inherent rights of individuals. In a speech in Philadelphia just after the Convention ended, James Wilson summarized the Federalist viewpoint: " $[\mathrm{I}] \mathrm{t}$ would have been superfluous and absurd, to have stipulated with a federal body of our own creation, that we should not enjoy those privileges, of which we are not divested either by the intention or the act that has brought that body into existence."'17

But the explanation by a rich Philadelphia lawyer of the niceties of natural law philosophy made little impression on the Antifederalists. To them the Constitution created a powerful new government that might easily abuse its powers; better to provide too many precautions

11 U.S. Const. art. I, § 9, cl. 2.

12 U.S. CoNST. art. I, $\S 9$, cl. 3.

13 U.S. CoNST. art. III, $\S 2$, cl. 3.

14 U.S. Const. art. III, § 3, cl. I.

15 See Main, The Antifederalists 158 (Quadrangle ed. 1964).

16 The terms "Federalist" and "Antifederalist" are used here as a shorthand form of expression. A Federalist is one who favored the ratification of the Constitution; an Antifederalist is one who for any reason opposed the new system of government embodied in the Constitution. MAIN, op. cit. supra note 15, at 119. Members of both factions, however, believed that the absence of a bill of rights was a notable omission. William Pierce may have reflected the existing mood when he wrote, in a letter dated Sept. 28, 1787: "some of the greatest men I ever knew have objected to the government for no other reason but because it was not buttoned with a Bill of Rights." 3 AM. Hist. REv. 315 (1898). Thomas Jefferson considered the lack of a bill of rights the greatest defect in the Constitution. Many Antifederalists based their opposition solely on this omission; one promised to "fall down, and worship it [the Constitution]" if a bill of rights were added. Rutzand, The Ordeal of THE Constitution 34 (1966). Rutland's book is only one of several that have recently shed light on the Antifederalists. See generally MAIN, THE ANTIFEderalists (Quadrangle ed. 1964); RosstTER, 1787: THE Grand ConveNTION (1966). WRIGHT, AMERIGAN INTERPRETATIONS OF NATURAI LAW (1962), provides further background.

17 PAMphlets on the Constitution 156 (Ford ed. 1888). 
than too few. They argued that by failing to limit the powers of the federal government, the rights of the people had been impliedly surrendered. James Winthrop of Massachusetts, for example, insisted that: "When the people institute government, they of course delegate all rights not expressly reserved."18

The ninth amendment had its genesis in the Federalist answer to this argument. The Federalists insisted that if a bill of rights were written, the fears of the Antifederalists would be realized, for an imperfect enumeration of rights would imply that other rights had indeed been given up to the federal government. As James Wilson later argued to the Pennsylvania ratifying convention:

[I]n a government consisting of enumerated powers, such as is proposed for the United States, a bill of rights would not only be unnecessary, but, in my humble judgment, highly imprudent. In all societies, there are many porvers and rights which cannot be particularly enumerated. . . . If we attempt an enumeration, everything that is not enumerated is presumed to be given. The consequence is, that an imperfect enumeration would throw all implied power into the scale of the government, and the rights of the people would be rendered incomplete. ${ }^{19}$

Although Wilson pushed through an early ratification in Pennsylvania, ratification in other states proved much more difficult. The Virginia Antifederalists, led by Patrick Henry, had an initial majority in the ratifying convention. Henry's argument was simple and appealing to delegates steeped in their state's tradition of democratic government and respect for individual rights:

It was expressly declared in our Confederation that every right was retained by the states, respectively, which was not given up to the government of the United States. But there is no such thing here. You, therefore, by a natural and unavoidable implication, give up your rights to the general government. ...

You have a bill of rights to defend you against the state government, which is bereaved of all power, and yet you have none against Congress, though in full and exclusive possession of all power. ${ }^{20}$

18 Essays on the Constitutron of the UNited States 112 (Ford ed. 1892).

192 Elliot, Debates on the Federal Constrtution 436 (1836) [hereinafter cited as ELtToT].

203 ELLIOT 446. The reference to "every right . . . retained by the states" may be confusing. Throughout this comment the word "right" refers to an inherent right re- 
James Madison, the leading Federalist spokesman in Virginia, attempted to counter Henry's view by advancing the two arguments which Wilson had suggested in Pennsylvania. First, Madison contended, a bill of rights was unnecessary because "the general government had no power but what was given it"21 and there had certainly been no delegation to the federal government of any power that would enable it to intrude upon the rights of individuals. Second, a bill of rights would be dangerous because it might then "be implied that every thing omitted is given to the general government." 22

The delegates, however, were insistent on a bill of rights. A number of them, led by Henry and George Mason, wanted to make ratification of the Constitution conditional on the passage of the desired amendments in the first session of Congress. Madison feared the impact such a conditional ratification would have on other states, especially New York, where the vote on ratification was then in grave doubt. His solution was to promise the delegates that he would submit the desired amendments to the first Congress if they would ratify without attached conditions. ${ }^{23}$

The promise to seek amendments apparently shifted the votes of enough delegates to permit ratification by a narrow margin..24 A number of proposed amendments and a suggested bill of rights were at-

tained by individuals, while "power" refers to the power of a state or the federal government. A state could, of course, retain power which has not been delegated to the federal government in the Constitution.

213 ELLrot 626.

223 Elliot 620. See also The Federalist No. 84, at 513 (Rossiter ed. 1961) (Hamilton).

23 Although Madison argued strongly against the need for a bill of rights during the Virginia convention, he felt himself bound by his promise to secure amendments and repeated it during the course of his campaign for election to the House of Representatives: "It is my sincere opinion that the Constitution ought to be revised, and that the first Congress meeting under it ought to prepare and recommend to the states for ratification the most satisfactory provisions for all essential rights, particularly the rights of conscience in the fullest latitude, the freedom of press, trials by jury, security against general warrants, etc." 3 BRANT, JAMres MADISON 240 (1950). By the time he introduced his proposed amendments, Madison had become strongly committed to them. See 1 ANnats of Congress 459-60 (Gales \& Seaton eds. 1834) [hereinafter cited as ANNALs]. (There are apparently two versions of this record for the First Congress. The one used here has the running page head "Gales \& Seaton's History of Debates in Congress." The other is an identical record but with the running page head "History of Congress" and different pagination.)

243 ELLIOT 657-62. RUTLAND, op. cit. supra note 16, at 250, states that the Antifederalists had been defeated on the ratification vote and that the Federalists allowed the opposition to attach a series of proposed amendments only as a sop. But the promise of Madison and other Federalists to press for adoption of certain amendments was at least a moral obligation, and it is probable, judging from Rutland's own description of the ratifying convention, that the promise of amendments was the factor which made ratification possible. 
tached to the resolution of ratification, with the request that Congress consider and enact them. ${ }^{25}$

Faced with strong opposition to the lack of a bill of rights, the Federalists in several other states agreed, as a matter of strategy, to accept the recommended amendments and press for their adoption in the new Congress. It was a shrewd political maneuver, for it negated the most appealing argument of the Antifederalists ${ }^{26}$ and probably converted many lukewarm opponents to ratification. "Thus a few Antifederalists - just enough-felt that the Constitution was better than 'anarchy and confusion,' and the promise of amendments was enough to quiet their fears." ${ }^{27}$ Similar concessions were made in Massachusetts, South Carolina, and New York, and may have provided the margin needed for ratification in each of those crucial states.

\section{The Ninth Amendment}

With the Constitution ratified by a sufficient number of states and the new government in operation, the House of Representatives assembled a quorum on April 1, 1789. On May 4, Madison served notice of his intention to submit several amendments to the Constitution..$^{28}$ The original proposal for the ninth amendment read:

253 ELLror 657-61. The seventeenth Virginia resolution was probably the original model for the ninth amendment:

That those clauses which declare that Congress shall not exercise certain powers, be not interpreted, in any manner whatsoever, to extend the powers of Congress; but that they be construed either as making exceptions to the specified powers where this shall be the case, or otherwise, as inserted merely for greater caution.

3 ELIror 661. Similar suggested amendments were advanced by New York, I Euluor 327-29; North Carolina, 4 ELliot 244-47; and Rhode Island, 1 ElLior 336-37. The Virginia amendment was specifically drawn to negate the Federalists' "imperfect enumeration" argument. See text accompanying note 19 supra.

26 Later events proved that the complaints of the Antifederalists over the omission of a bill of rights were in part aimed at attracting sympathy. It appears that many Antifederalists intended to use the occasion of ratification of the amendments, once they were passed by Congress, to call a second constitutional convention to undo the work of the first convention altogether. "[T]he clamor for a bill of rights [was a] meaningless gesture ...., in the eyes of leading Antifederalists, if another meeting were not called to implement their program." RutLand, The Ordeal of the ConstrTution 37 (1966).

These Antifederalists, however, miscalculated. The promised amendments satisfied most critics of the Constitution. That the staunch Antifederalists never intended the bill of rights to serve as a substantive guarantee is shown by the fact that they opposed the amendments which Congress later passed and sent to the states for ratification. See Rossiter, 1787: THE GRAND CoNvention 304 (1966).

27 MAIN, The ANTIFEDERALists 256 (Quadrangle ed. 1964).

28 I ANNALS 257. Madison's early notification to the House that he would propose amendments, and his insistence on their early consideration, were designed to thwart 
The exceptions here or elsewhere in the constitution, made in favor of particular rights, shall not be so construed as to diminish the just importance of other rights retained by the people, or as to enlarge the powers delegated by the constitution; but either as actual limitations of such powers, or as inserted merely for greater caution. ${ }^{29}$

In his introductory remarks, Madison stated, in reference to the above proposal:

It has been objected also against a bill of rights, that, by enumerating particular exceptions to the grant of power, it would disparage those rights which were not placed in that enumeration; and it might follow, by implication, that those rights which were not singled out, were intended to be assigned into the hands of the General Government, and were consequently insecure. This is one of the most plausible arguments I have ever heard urged against the admission of a bill of rights into this system; but, I conceive, that it may be guarded against ... [by the proposed amendment].$^{30}$

Eventually the House formed a select committee, of which Madison was a member, to review the proposals. ${ }^{31}$ While the amendment was in committee it underwent an important revision. Madison's original proposal had contained two parts, the second of which stated that the enumeration of certain rights should not be construed "to enlarge the powers delegated by the constitution." This section was stricken in the select committee, which reported back the ninth amendment in virtually final form: "The enumeration in this Constitution of certain rights shall not be construed to deny or disparage others retained by the people." 32

The changes made in the select committee reveal an important crys-

an Antifederalist plan to move for a second constitutional convention. As Madison had hoped, such a motion was later voted down. Id. at 258-261. See note 26 supra.

20 I ANnals 451-52. Compare the seventeenth Virginia Resolution, quoted note 25 supra.

301 Annars 456. Here Madison was giving primary emphasis to the second Federalist argument against a bill of rights: that "particular exceptions to a grant of power" would imply a surrender of unenumerated rights.

31 Id. at $690-91$.

32 Id. at 783. There is unfortunately no record of the proceedings of the select committee of the House which revised the ninth amendment. The debate in the House itself was limited to a motion to change "disparage" to "impair," which was defeated. Ibid. Nor is there any record of the changes from "this" to "the" and the insertion of commas which completed the form of the ninth amendment as it now appears. 
tallization in Madison's attitude toward individual rights and governmental powers. He believed that the Constitution should contain a certain amount of flexibility in its grant of governmental power and that strict limitations on the power of Congress would be unworkable and might at any rate be ignored. ${ }^{33}$ To Madison the necessary and proper clause was a vital part of the Constitution, "for in every new application of a general power, the particular powers, which are the means of attaining the object of the general power, must always necessarily vary with that object, and be often properly varied whilst the object remains the same." ${ }^{4}$ Madison regarded the tenth amendment as the only explicit limitation on federal power to be found in the Constitution; $^{35}$ the protection of individual rights was to be accomplished by the specific guarantees of the first eight amendments, as well as the ninth. ${ }^{36}$

This separation of rights and powers into the first nine and the tenth amendments, respectively, meant that the reach of governmental power, whether exercised through specific sections of the Constitution or through the necessary and proper clause, ended at the point where the scope of individual rights protected by the first nine amendments

33 See Brant, op. cit. supra note 28.

34 The Federarist No. 44, at 285 (Rossiter ed. 1961) (Madison); see Crosskey, Polincs AND the Constitutron 684 (1953). Madison altered his views on the efficacy of the necessary and proper clause rather sharply in later years. See Rogge, op. cit. supra note 2, at $794-96$.

35 The tenth amendment states: "The powers not delegated to the United States by the Constitution, nor prohibited by it to the States, are reserved to the States respectively, or to the people." At one point in the House debates on the tenth a motion was made to insert the word "expressly," so that it would read, "The powers not expressly delegated to the United States . . . Madison opposed this change, arguing that "it was impossible to confine a Government to the exercise of express powers; there must necessarily be admitted powers by implication." I ANNals 790. The proposed amendment was not adopted by Congress. Ibid. An identical motion was made several days later and also failed. Id. at 797.

36 Edmund Randolph, then the governor of Virginia and a reluctant Federalist, argued that this reformulation of the ninth amendment left "no criterion by which it could be determined whether any other particular right [beside those specified in the other amendments] was retained or not." 4 SPARKs, CoRrespondence of THE AMERICAN RevoIUTION 298 (1853). Madison interpreted this to mean that Randolph preferred the original formulation of the ninth, prohibiting extension of the powers of Congress and answered that "if a line can be drawn between the powers granted and the rights retained, it would seem to be the same thing, whether the latter be secured by declaring that they shall not be abridged, or that the former shall not be extended." 5 THE WRIrings of James Madison 431-32 (Hunt ed. 1904).

This analysis can hardly be accepted. Casting the ninth in terms of restrictions on governmental power, rather than as an affirmation of individual rights, would have made it a specific limitation on the necessary and proper clause, something Madison wanted very much to avoid. See Dunbar, supra note 2, at 633-35. 
began; the two spheres were mutually exclusive. Madison illustrated this belief by pointing out that general warrants could not be used to collect taxes: ${ }^{37}$ There was no doubt that the necessary and proper clause gave the government whatever powers might be necessary to collect revenues, but the revenue power could not extend so far as to infringe the right to be free from general warrants which the fourth amendment proscribed. ${ }^{38}$

The history thus far presented suggests that the ninth amendment expresses the political philosophy that prevailed in Madison's timeindividual rights exist independently of government power-and that it was written to avoid any implication that the enumeration of rights in the first eight amendments was to be an exhaustive catalogue. In this view, the ninth is not to be read as a summary or source of unenumerated rights, but rather as a rule of construction stating that the enumeration of some rights does not deny the existence of others.

There is, however, other historical evidence which appears to yield a different conclusion. ${ }^{39}$ On October 17,1788 , after the close of Virginia's ratifying convention, Madison wrote a letter to Thomas Jefferson, then Minister to France, which included the following:

My own opinion has always been in favor of a bill of rights; provided it be so framed as not to imply powers not meant to be included in the enumeration. At the same time, I have never thought the omission a material defect. ... I have not viewed the matter in an important light-1. Because I conceive that in a certain degree, though not in the extent argued by $\mathrm{Mr}$. Wilson, the rights in question are reserved by the manner in which the federal powers are granted. 2. Because there is great reason to fear that a positive declaration of some of the most essential rights could not be obtained in the requisite latitude. I am sure that the rights of conscience, in particular, if submitted to public definition would be narrowed much more than they are likely to be by an assumed power. ${ }^{40}$

371 ANNALS 456.

38 Compare the language of Mr. Justice Reed in United Public Workers v. Mitchell, 330 U.S. 75 (1947), quoted in the text accompanying note 50 infra.

39 See Kelly, supra note 5 , at 152-53.

4014 Papers of Thomas Jefrerson 18 (Boyd ed. 1958). Jefferson considered the lack of a bill of rights in the Constitution as its "principal defect." 12 PAPERs of Thomas JeFFERSON 569-70 (Boyd ed. 1958). See also id. at 440. This may explain Madison's sudden enthusiasm for a bill of rights in a letter to his old friend. Jefferson's reply also indicates that he did not accept the argument that the federal government was composed only of delegated powers, an argument which would make a bill of rights unnecessary. 14 Papers of Thomas Jefferson 660 (Boyd ed. 1958). 
Madison's fear was simply that definitions of specific rights which required ratification by Congress and the states might not be as broadly stated as he would prefer. Can it then be said that Madison wrote the ninth amendment in the hope that it might someday be construed to include other rights he could not include because of the political exigencies of the moment? ${ }^{41}$

Perhaps an answer can be found by considering Madison's example of the right of conscience. Professor Brant makes clear in Madison's biography that "Madison looked upon liberty of conscience as the fundamental factor in freedom of religion, and religious freedom, to judge from the concentrated attention he gave it, as the fundamental freedom." 42 When Madison wrote to Jefferson, his past experience gave him reason to fear that it might be impossible to secure an amendment granting complete religious freedom. He had failed to secure such a guarantee when he wrote the religious freedom article of the Virginia Declaration of Rights, although he had secured a change that guaranteed free exercise of religion as opposed to mere toleration in its exercise. ${ }^{43}$

If these were the difficulties encountered in Virginia, it might have proved much more difficult to secure a satisfactory response from those states that had established churches. ${ }^{44}$ Nevertheless, Professor Brant indicates that when Madison introduced what became the first amendment, he put forward a proposal that would guarantee total religious freedom and prevent any attempt by Congress to favor one religious sect over another. Moreover, Madison tenaciously defended his proposal in the House and wrote all the succeeding drafts of the amend. ment. The House amendment sent to the Senate read: "Congress shall make no law establishing religion, or to prevent the free exercise thereof, or to infringe the rights of conscience." 45 When the Senate emasculated this version, Madison, as chairman of the House conferees, was successful in having his final House version reinstated. The "rights of conscience" clause was eliminated, but the sense of Madison's version-total separation of church and state and exclusion of outright governmental aid to any religion-was preserved.

If Madison had drafted the ninth amendment intending to cover sub silentio those aspects of religious freedom that he might not have

41 Kelly, supra note 5, at 153.

421 Brant, James Madison 243 (1941).

43 See $i d$. at $\mathrm{ch}$. XII; I The PAPERS of JaMes Madison 170-79 (Hutchinson \& Rachal eds. 1962).

44. See 3 BRANT, op. cit. supra note 23, at 268-69.

$45^{\circ} I d$. at 271. Brant attributes this version directly to Madison. 
been able to include in the first amendment, such a purpose was probably forgotten with the success of achieving the broad guarantees of the first. There is no record in any of Madison's statements that he feared the difficulty of defining other individual rights. Moreover, none of the states' suggested amendments relating to fundamental rights were omitted by Madison in his proposals for a national bill of rights. ${ }^{46}$

It must also be asked whether Madison's statement to Jeffersonthat it might be impossible to secure an acceptable definition of rights of conscience-is substantively different from the Federalist argument that an enumeration of certain rights would imply that everything not enumerated was given up. ${ }^{47}$ If Madison intended the ninth to make the "imperfect enumeration" theory untenable, a failure to define the full scope of freedom of religion would no more imply that some aspect of it had been surrendered than would the total exclusion of the first amendment from the Bill of Rights. In summary, whether one reads the history of the ninth as foreclosing the "imperfect enumeration" theory, or as attempting to avoid future definitional problems, the amendment clearly remains a rule of construction with the purpose of obviating the possibility of interpreting the first eight amendments as exclusive. It is not, as its history indicates, either a source or a summary of those unenumerated rights.

\section{The Ninth in the Supreme Court}

A number of Supreme Court decisions which might have drawn support from the ninth amendment have, in fact, not even mentioned it. One group of such cases has derived rights not mentioned in the Constitution solely from considerations of due process. ${ }^{48} \mathrm{~A}$ second group

46 This point was checked by examining all of the bills of rights proposed by the state ratifying conventions, as these are reprinted in the several volumes of ELIIOT. This is not to say that Madison did not eliminate a great deal of duplication and fuzzy wording when he wrote his amendments; the substance, however, is preserved. It need hardly be added that Madison ignored many suggested amendments included in these bills of rights that were actually restrictions on the power of the federal government rather than affirmations of rights.

47 Professor Kelly suggests that there is a sharp distinction between Madison's fear in his letter to Jefferson that an imperfect definition of rights might imply that only enumerated rights were to be protected, and the Federalist concern that an imperfect definition of rights would imply that all other rights had been given up to the federal government and thus subjected to substantive legislation. Kelly, supra note 5, at 153 . But Madison's own statement to the House of Representatives at the time the ninth was introduced, see note $\mathbf{3 0}$ supra, indicates that he saw no such distinction. To him, if unenumerated rights were not to be protected, the implication might be that those rights had been surrendered to the new government.

48 See, e.g., Aptheker v. Sec'y of State, 378 U.S. 500 (1965); Kent v. Dulles, 357 U.S. 
has recognized the fundamental idea of the ninth amendment-that individuals possess inherent rights beyond the effective control of any government:

There are certain vital principles in our free republican governments, which will determine and overrule an apparent and flagrant abuse of legislative power; as to authorize manifest injustice by positive law; or to take away that security for personal liberty, or private property, for the protection whereof the government was established..$^{49}$

Only a few modern cases have dealt with the ninth amendment directly. United Public Workers $v$. Mitchell, ${ }^{50}$ which tested the constitutionality of the Hatch Act's ${ }^{51}$ prohibition of political activity, was the first of these. Unfortunately, Mr. Justice Reed's opinion for the majority distorted the concept of individual rights that the Court had earlier recognized:

Of course, it is accepted constitutional doctrine that these fundamental human rights are not absolutes. . . . Therefore, when objection is made that the exercise of a federal power infringes upon rights reserved by the Ninth and Tenth Amendments, the inquiry must be directed toward the granted power under which the action of the Union was taken. If granted power is found, necessarily the objection of invasion of those rights, reserved by the Ninth and Tenth Amendments, must fail. ${ }^{52}$

116,125 (1958) ("The right to travel is a part of the 'liberty' of which the citizen cannot be deprived without due process of law'); Schware v. Board of Bar Examiners, 353 U.S. 232 (1957) (a state cannot, consistently with due process, refuse a lawyer a license to practice law where the record does not support a finding that he was morally unfit); Pierce v. Society of Sisters, 268 U.S. 510 (1925) (a state cannot consistently with due process enact a statute requiring all children to attend public schools); Meyer v. Nebraska, 262 U.S. 390 (1923) (a state statute which prohibits the teaching of modern foreign languages is a deprivation of liberty without due process).

49 Calder v. Bull, 3 U.S. (3 Dall.) 386, 388 (1798). Of similar import is the statement in Loan Ass'n v. Topeka, 87 U.S. (20 Wall.) 655, 662-63 (1874): "It must be conceded that there are such rights in every free government beyond the control of the State. . . There are limitations on such power which grow out of the essential nature of all free governments. Implied reservations of individual rights, without which the social compact could not exist, and which are respected by all governments entitled to the name." [sic]

50330 U.S. 75 (1947).

5160 Stat. 937 (1946), as amended, 76 Stat. 750 (1962), 5 U.S.C. $\S 118$ (1964).

52330 U.S. at 95-96. Compare note 49 supra. See also the dictum of Chief Justice Marshall in McCulloch v. Maryland, 17 U.S. (4 Wheat.) 316 (1819): "Let the end be legitimate, let it be within the scope of the constitution, and all means which are appropriate, which are plainly adapted to that end, which are not prohibited, but consist with the letter and spirit of the constitution, are constitutional." Id. at 421; see Ex parte Kurth, 28 F. Supp. 258 (S.D. Cal. 1939). 
Mr. Justice Reed's error stemmed from a basic misconception as to the meaning of the ninth amendment. It has already been noted that in drafting the ninth, Madison was intent on clearly separating rights and powers. The powers of the federal government extended, through the operation of the necessary and proper clause, as far as necessary to carry out the objects of the Constitution, but in no case could they transgress the limitations imposed by individual rights. ${ }^{53}$ Thus to say, as Mr. Justice Reed did, that the existence of granted power overcomes "the objection of invasion of rights" is to destroy the separation of powers and rights that Madison meant to solemnify in the ninth. The important question is the one Mr. Justice Reed never asked in Mitchell: Is the right to engage in political activity a fundamental right? ${ }^{24}$

Mr. Justice Brennan's opinion in Roth $v$. United States ${ }^{55}$ provides an instructive contrast to Mitchell. He used the language of Mr. Justice Reed in dealing with the contention that a federal statute prohibiting the mailing of obscene material was an unconstitutional exercise of the postal power because it infringed the rights guaranteed in the first amendment. Although he uncritically accepted Mr. Justice Reed's language, Mr. Justice Brennan, in upholding the statute, was careful to point out that it was valid not because the postal power was superior to the rights protected by the first amendment, but because "obscenity is not expression protected by the First Amendment." 56

53 See text accompanying notes $36-38$ supra.

54 Dunbar, supra note 2, at 643, reaches the same conclusion: "Justice Reed's language is not justified when the ninth amendment is understood to mean that by enumeration of rights in the Constitution nothing has been lost; that the rights of the people would have rested on as firm ground without enumeration, because they do not lie within the purview of the powers granted to Congress; that the fact of the enumeration of rights adds nothing to the objects of government ...."

55354 U.S. 476 (1957).

58 Id. at 492. In two earlier cases in the Supreme Court, Ashwander v. Tennessee Valley Authority, 297 U.S. 288 (1936) and Tennessee Elec. Power Co. v. Tennessee Valley Authority, 306 U.S. 118 (1939), the constitutionality of the act creating the TVA was challenged. In each, the ninth amendment was advanced to support the argument that individuals have an inherent right to acquire property and employ it in a lawful business, and that the competition offered by the TVA's lower electric power rates was therefore unconstitutional. The Court in each case decided that the competition was the incidental result of the government's operation of electric power facilities, justifable under the war power. It thus did not have to reach the ninth amendment question: "And the Ninth Amendment ... does not withdraw the rights which are expressiy granted to the Federal Government." 297 U.S. at 330-31.

There have been numerous lower federal court cases in which the argument was advanced that the ninth forbids the exercise of certain governmental powers which allegedly violate individual rights. In most of these cases the contention is rejected outright. See, e.g., Welchel v. McDonald, 176 F.2d 260 (5th Cir. 1949), aff'd, 340 U.S. 122 (1950) (ninth does not give an enlisted man the right to have enlisted men on a court martial); Commonwealth \& Southern Corp. v. SEC, 134 F.2d 747 (3d Cir. 1943) (ninth does not 
Griswold $v$. Connecticut ${ }^{5 \tau}$ includes the most recent interpretation of the ninth amendment. In that case the appellants, who had counseled married persons in the use of contraceptive devices, were convicted of aiding and abetting a violation of a Connecticut statute that prohibited the use of any such device. ${ }^{58}$ The Supreme Court, in a 7-2 decision, reversed the convictions. ${ }^{59}$

It is difficult to ascertain the grounds on which the majority based its decision. Mr. Justice Douglas' opinion for the Court referred to the first, third, fourth, fifth, ninth and fourteenth amendments. But as Mr. Justice Stewart pointed out in dissent, nowhere did Mr. Justice Douglas say "which of these Amendments, if any, [he] thinks is infringed by this Connecticut law."60 The central point of the majority opinion appears to be that each of the mentioned amendments has "penumbras, formed by emanations from those guarantees that help give them life and substance," and that these "various guarantees create zones of privacy." 61 The right of married people to the privacy of their

give a right to have an SEC order to change corporate name vacated); Glay v. City of Eustis, 7 F.2d 141 (S.D. Fla. 1925) (extension of city boundaries by a state legislature); United States v. Fujimoto, 102 F. Supp. 890 (D. Hawaii 1952) (statute prohibiting advocating overthrow of the federal government); United States v. Painters Local 481, 79 F. Supp. $516(\mathrm{D}$. Conn. 1948) (prohibition of expenditures by corporations and labor unions to political campaigns); National Maritime Union v. Herzog, 78 F. Supp. 146 (D.D.C. 1948) (inclusion of anti-communist provisions in labor-management legislation); Ex parte Kurth, 28 F. Supp. 258 (S.D. Cal. 1939) (ninth is not a basis for a right of asylum).

Ex parte Kurth contains language which, like Mitchell, indicates a misunderstanding of the ninth amendment: the Constitution "does not confer any rights except in the instances where those rights are specifically enumerated." $28 \mathrm{~F}$. Supp. at 264 . It is contended in this Comment that the Constitution does not confer any rights at all; rights exist independently of, and prior to, any written instrument of government, although the Constitution may provide the tool for the protection of certain rights.

57381 U.S. 479 (1965).

58 The decision below is reported at 151 Conn. 544, 200 A.2d 479 (1965). See Note, Connecticut's Birth Control Law: Reviewing a State Statute under the Fourteenth Amendment, 70 YALE L.J. 322 (1960).

59 Only Justices Stewart and Black dissented. Mr. Justice Goldberg wrote a concurring opinion for himself, Chief Justice Warren, and Mr. Justice Brennan. Justices Harlan and White concurred separately.

60381 U.S. at 528.

$61 I d$. at 484 . The existence of the right of privacy to which Mr. Justice Douglas refers throughout his opinion was first suggested in Warren \& Brandeis, The Right to Privacy, 4 HARV. L. REv. 193 (1890). In several early cases the fourth amendment was interpreted in terms of a right of privacy. See, e.g., Olmstead v. United States, 277 U.S. 438,478 (1928) (Brandeis, J., dissenting) (the Constitution confers, "as against the Government, the right to be let alone-the most comprehensive of rights and the right most valued by civilized men'); Boyd v. United States, 116 U.S. 616 (1886). Later fourth amendment cases have retreated from this broad interpretation. See, e.g., On Lee v. United States, 343 U.S. 747 (1952); Goldman v. United States, 316 U.S. 129 (1942). See generally on the right to privacy, Mapp v. Ohio, 367 U.S. 643 (1961); Poe v. Ullman, 367 U.S. 497, 517 
bedrooms, the opinion concluded, falls "within the zone of privacy created by several fundamental constitutional guarantees." 62

Mr. Justice Goldberg's opinion accorded the ninth greater attention than it has received in any previous Supreme Court case. ${ }^{63} \mathrm{He}$ began with the forthright declaration that "the concept of liberty protects those personal rights that are fundamental, and is not confined to the specific terms of the Bill of Rights." ${ }^{44} \mathrm{He}$ continued:

My conclusion that the concept of liberty is not so restricted [to the specific terms of the Bill of Rights] and that it embraces the right of marital privacy though that right is not mentioned explicitly in the Constitution is supported both by numerous decisions of this Court, . . . and by the language and history of the Ninth Amendment.

The language and history of the Ninth Amendment reveal that the Framers of the Constitution believed that there are additional fundamental rights, protected from government in-

(1961) (Douglas, J., dissenting); Frank v. Maryland, 359 U.S. 360 (1959); Public Utilities Comm'n v. Pollack, 343 U.S. 451, 467 (1952) (Douglas, J., dissenting); Skinner v. Oklahoma, 316 U.S. 535, 541 (1942).

Analytically, privacy has both tort and constitutional aspects. The tort aspects are considered in Prosser, Privacy, 48 CALIF. L. Rev. 383 (1960), and Prosser, TorTs, § 112 (3d ed. 1964). On privacy as a constitutional question, see, e.g., Beaney, The Constitutional Right to Privacy in the Supreme Court, 1962 SUP. Cr. REv. 212; Griswold, The Right to be Let Alone, 55 Nw. U.L. REv. 217 (1960); Pound, The Fourteenth Amendment and the Right of Privacy, 13 W. Res. L. REv. 34 (1961); Yankwich, The Right of Privacy, Its Development, Scope and Limitations, 27 NOTRE DAME LAw. 499 (1952). A forthcoming issue of Law and Contemporary Problems will contain a series of articles on the right of privacy and its various aspects.

62381 U.S. at 485 . Mr. Justice Douglas' opinion suffers from a substantial logical inconsistency. In speaking of the "penumbras" of the first amendment, he stated that the right to association, NAACP v. Alabama, 357 U.S. 449,462 (1958), the right to teach, Barenblatt v. United States, 360 U.S. 109, 112 (1959); Sweezy v. New Hampshire, 354 U.S. 234, 349.50, 361-63 (1957), and the right to be heard, Sain v. New York, 334 U.S. 558 (1948), are among the "emanations" that help give meaning to the first. The 'Court has generally held that "the protection of the Bill of Rights goes beyond the specific guarantees to protect ... those equally fundamental personal rights necessary to make the express guarantees fully meaningful." Lamont v. Postmaster General, 381 U.S. 301, 308 (1965) (Brennan, J., concurring). But in speaking of the right of marital privacy as one lying "within the zone of privacy," Mr. Justice Douglas had no specific constitutional guarantee upon which to rely, as he did in relating the right of association to the first amendment. Instead, he was compelled to refer to the "penumbras" of "several fundamental constitutional guarantees." The only amendments that furnish any direct support for his interpretations are the fourth and fifth, and those only if an expansive interpretation is given them. See note 61 supra.

63381 U.S. at 486 . The ninth amendment was barely mentioned in the brief. See Brief for the Appellants, pp. 82-83.

64381 U.S. at 486 . 
fringement, which exist alongside those fundamental rights specifically mentioned in the first eight amendments. ${ }^{65}$

He then recounted the highlights of the ninth's enactment, and correctly pointed out that the ninth was designed to make clear that the enumeration of certain rights in the first eight amendments was not to be construed as a denial that others might also be protected. From these points his conclusion quickly followed:

These statements of Madison ... make clear that the Framers did not intend that the first eight amendments be construed to exhaust the basic and fundamental rights which the Constitution guaranteed to the people.

To hold that a right so basic and fundamental and so deeprooted in our society as the right of privacy in marriage may be infringed because that right is not guaranteed in so many words by the first eight amendments to the Constitution is to ignore the Ninth Amendment and give it no effect whatsoever. ${ }^{66}$

So straightforward-and to some so appealing-is this conclusion that the unarticulated premise is almost missed. The premise is that the right of privacy in marriage is classifiable, like freedom of religion or the right to a jury trial, as a fundamental right. There is little support in his opinion for this important assumption; the manner in which it was made deserves further consideration. ${ }^{67}$ Otherwise, there should be no disagreement with Mr. Justice Goldberg's handling of the ninth amendment. He carefully noted that it is not "an independent source of rights." 68 Rather, "the Ninth Amendment simply lends strong support" to his conclusion that the due process clause of the fourteenth amendment prohibits Connecticut from infringing the right of marital privacy by this statute. ${ }^{69}$

65 Id. at $486-87,488$.

66 Id. at 490, 491. Like Mr. Justice Douglas, Mr. Justice Goldberg derives a right of marital privacy by first assuming that the "right of privacy is a fundamental personal right, emanating 'from the totality of the constitutional scheme under which we live." Id. at 494 . See note 61 supra.

67 For discussion of this point see text accompanying notes 76-80 infra.

68381 U.S. at 492 . Several commentators have misinterpreted Mr. Justice Goldberg's opinion on this point. See, e.g., 40 TuL. L. REv. 418, 421 (1966) (the use of the ninth amendment as showing the existence of fundamental rights indicates that it "in itself protects the individual's fundamental rights"); 5 Washburn L.J. 286, 288 (1966).

69381 U.S. at 492, 493: "[T] $]$ he subsequently enacted Fourteenth Amendment prohibits the States ... from abridging fundamental personal liberties." For Mr. Justice Goldberg, a right is fundamental if it is one "so rooted in the traditions and conscience of our 
Of the other opinions, only Mr. Justice Black's requires discussion. ${ }^{70}$ His dissent was predictably cast as a charge that the majority had struck down a statute which the judges found irrational and offensive, but which, he said, was nowhere forbidden by the Constitution. In particular, he insisted that there was no constitutional provision protecting the right of privacy, and that the fourth amendment's guarantee against unreasonable searches and seizures did not protect such a right. To him, this substitution of "words, more or less flexible and more or less restricted in meaning," was "one of the most effective ways of diluting or expanding a constitutionally guaranteed right."71

To Mr. Justice Black, the ninth amendment is merely a substitute for the due process clause, both of which are used "to strike down all state legislation which this Court thinks violates 'fundamental principles of liberty and justice." "72 He reads the ninth as intended not to guarantee unenumerated rights, but rather "to assure the people that the Constitution in all its provisions was intended to limit the Federal

people as to be ranked as fundamental." See Snyder v. Massachusetts, 291 U.S. 97, 105 (1934) (Cardozo, J.). Fundamental rights, thus, are not confined to the specific terms of the Bill of Rights. 381 U.S. at 486.

It has generally been understood that the Bill of Rights applies only to the federal government. An amendment proposed by Madison that would have specifically prohibited the states from violating "the equal rights of conscience, or the freedom of the press, or the trial by jury in criminal cases," 1 ANNALs 452, was eliminated by the Senate. Since the decision in Barron v. Baltimore, 32 U.S. (7 Pet.) 242 (1833), it has been established that the Bill of Rights does not apply to the states. But see CrosskeY, Politics AND tHE Consitrution 1076-82 (1953). Although a few later cases have stated that only the first eight amendments apply to the federal government, see, e.g., Palko v. Connecticut, 302 U.S. 319, 322 (1937); Bolin v. Nebraska, 176 U.S. 83, 88 (1900); Eilenbecker v. District Court, 134 U.S. 31, 35 (1890), there is nothing to support the conclusion that the ninth amendment is directly applicable to the states. But see Patrerson, The Forgotten Ninty AMENDMENT 28-29 (1955). Indeed, in Brown v. New Jersey, 175 U.S. 172, 174 (1899), the Court cited both the Barron and Eilenbecker cases for the proposition that "the first ten amendments . . . were intended to operate solely on the Federal Government." Justice Brown, who wrote the opinion in Bolin v. Nebraska, was a member of the majority in Brown v. New Jersey.

70381 U.S. at 507. The opinion of Mr. Justice Harlan, id. at 499, could have been predicted from his dissenting opinion in Poe v. Ullman, 367 U.S. 497, 522 (1961). Applying an outright substantive due process concept, he found the Connecticut law violative of the "basic values 'implicit in the concept of ordered liberty," 381 U.S. at 500, and thus invalid under the fourteenth amendment. Mr. Justice White found a violation of the due process clause because the statute was not reasonably related to its avowed objective of inhibiting illicit sexual relationships. $I d$. at 505. Clearly this analysis was offered to the Court as an escape route from having to hold the statute unconstitutional on substantive due process grounds. Except for a passing reference in Mr. Justice Goldberg's opinion, the Court did not choose to follow Mr. Justice White's lead. Mr. Justice Stewart essentially restated Mr. Justice Black's dissent. Id. at 527.

71381 U.S. at 509.

$72 I d$. at $518-19$. 
Government to the powers granted expressly or by necessary implication ... (and also) to protect state powers against federal invasion."73

Such a reading of the ninth amendment is clearly wrong; ${ }^{74}$ it is the tenth amendment that protects state powers against federal encroachment and that limits the federal government to the exercise of express and implied powers. ${ }^{75}$ The ninth amendment deals with the distribution or exercise of governmental power only in that it prohibits intrusions into the area of individual rights.

Mr. Justice Goldberg did not use the ninth to strike down a state law which in his view violated an inherent individual right, as $\mathrm{Mr}$. Justice Black accused him of doing. His invalidation of the Connecticut contraceptive law was based squarely on the due process clause of the fourteenth amendment; the ninth amendment merely aided him in concluding that the right of marital privacy may have been one of those "others retained by the people."

\section{The Search for Rights}

The flaw in Mr. Justice Goldberg's opinion, as hinted earlier, stems not from his analysis of the ninth, but rather from his conclusion that the right of marital privacy is one of those inalienable but unenumerated rights to which the ninth refers. He made little effort to show that marital privacy deserved classification as a fundamental personal right, beyond citing dicta in several cases to the effect that there exists a sphere of family life which is protected from state encroachment. ${ }^{76}$

Yet, if Mr. Justice Goldberg had attempted to dig back through history to discover whether the right of marital privacy was "inherent," he probably would have been unsuccessful. Nor does a reliance on

73 Id. at 520. See Kelly, supra note 5 , at 152.

74 This reading of the ninth may have been quite deliberate on Mr. Justice Black's part. In his view, the due process clause of the fourteenth amendment incorporates those rights specifically enumerated in the first eight amendments, and no others. Adamson v. California, 332 U.S. 46, 68 (1947) (Black, J., dissenting). That theory is of course inconsistent with the open-ended meaning of the due process clause of the fifth amendment. See id. at 66-67 (Frankfurter, J, concurring). It is also untenable if the ninth amendment is read as pointing to other unenumerated rights, as this comment suggests. Mr. Justice Black treats the first eight amendments as an exclusive catalogue-the very treatment that Madison, in proposing the ninth, sought to avoid.

75 See note 35 supra.

76 See, e.g., Prince v. Massachusetts, 321 U.S. 158, 166 (1944) ("these decisions have respected the private realm of family life which the state cannot enter"); Pierce v. Society of Sisters, 268 U.S. 510 (1925); Meyer v. Nebraska, 262 U.S. 390 (1923). Mr. Justice Goldberg's failure to chart the course by which he discovered this protected right drew sharp censure from Mr. Justice Black. 381 U.S. at 521. Cf. Baldwin v. Missouri, 281 U.S. 586, 595 (1930) (Holmes, J., dissenting). 
history necessarily help matters; the Supreme Court has discovered that history can retard as well as aid the development of the due process clause. In Twining $v$. New Jersey, ${ }^{77}$ the Court considered whether a state must extend the privilege against self-incrimination to a defendant. Adopting an historical approach, it examined the past and found no evidence of the existence of that right at common law. ${ }^{78}$ It was not until 1964 that the Court, using an outright procedural due process test, finally overruled Twining in Malloy v. Hogan. ${ }^{79}$

The major difficulty with an historical approach, beyond the obvious one that the questions in issue are peculiarly modern, is one which has already been noted: in the eighteenth century inherent rights were generally somewhere written down.

Natural-law theory, in which Madison and the other political leaders of the Revolutionary era were steeped, was a large and expansive notion. But it was not limitless. On the contrary, in the recent quarrel with Britain, the Americans had sought to define their rights very specifically.

Ultimately, Revolutionary natural-rights theorists insisted, liberty was derived from a state of nature, but it had long since been given a very positive and specific content. It was to be found in the Magna Carta, in the Petition of Rights, in the Bill of Rights of 1689 , and above all in the common law, as expounded by Coke and Blackstone in their commentaries. ${ }^{80}$

This theory of a written bill of rights does not necessarily make the ninth amendment superfluous; after all, Madison included it in the Bill of Rights to meet the Federalist argument that an enumeration of rights might be incomplete, thereby implying a surrender of the unenumerated rights. But it does illustrate the difficulty of finding new individual rights.

The American experience with a written set of inalienable rights introduces a further problem that may be the cause of the continuing controversy in the Court over the determination of the rights that are

77211 U.S. 78 (1908).

78 The Court's decision to use such an analysis was prompted by Justice Curtis' dictum in Murray v. Hoboken Land \& Improvement Co., 59 U.S. (18 How.) 272 (1855), that in determining whether a given right should be classified as fundamental, "we must look to those settled usages and modes of procedure existing in the common and statue [sic] law of England." Id. at 277; Cf. Singer v. United States, 380 U.S. 24 (1965). 79378 U.S. 1 (1964).

80 Kelly, Clio and the Court: An Illicit Love Affair, 1965 Sur. Cr. REv. 119, 154-55. See also Kurland, Magna Carta and Constitutionalism in the United States: "The Noble Lie," in The Great Charter 48 (1965). 
to be protected by the due process clause. The Magna Carta and the later English bills of rights were essentially guarantees that the monarch would not interfere with certain rights of his subjects. It was the duty of Parliament to protect and enforce these rights and guard their vitality. This view was carried over into the early American state constitutions, none of which made any provision for judicial review to enforce individual rights. ${ }^{81}$ It was not until after the Constitution was written that the practice of judicial review became well established. ${ }^{82}$

Whatever the benefits of judicial review in the United States, one may be sure that the doctrine has contributed significantly to the present conflict between the strict constructionists such as Mr. Justice Black ${ }^{83}$ and those, like Justices Harlan and Goldberg, who do not limit themselves to the guarantees of the first eight amendments in determining those rights implicit in the concept of due process. ${ }^{84}$ Indeed, in Griswold, Mr. Justice Stewart suggested, not for the first time in the Supreme Court, that a return to the principles of Magna Carta might be in order:

81 Kurland, supra note 80 , at 56 .

82 Professor Kurland explains this development as follows: "The novelty of the American Constitution-whether intended or not is still a matter of controversy-is to be found in the allocation to the judiciary of the power to restrain government action contravening the fundamental law. No longer were the people to be dependent upon the self-restraint of the legislature for assurance of the guarantees of freedom. The legislative supremacy Magna Carta had helped impose on the Crown in the seventeenth century was supplanted in the New World by judicial supremacy over the meaning of the fundamental law." Kurland, supra note 80, at 58. Judicial review was not unheard of before the time of the Constitution. In Dr. Bonham's Case, 8 Rep. 118a, Coke declared that "where an Act of Parliament is against common right and reason or repugnant or impossible to be performed, the common law will controul it and adjudge it to be void." Legislation of the American Colonies was reviewed by the Privy Council, see, e.g., McGovney, The British Origin of Judicial Review of Legislation, 93 U. PA. L. REv. I (1944). And there are several early state court cases enunciating the doctrine. See generally Dowling and Gunther, Cases on Constrtuttonal Law 19-27 (1965).

83 If anything, Mr. Justice Black is a liberal constructionist of the Bill of Rights, especially with regard to the first amendment. See Black, The Bill of Rights, 35 N.Y.U.L. REv. 865 (1960). The reference here is to his refusal to look outside the bounds of the first eight amendments, a procedure dictated by his incorporation theory. See note 74 supra.

84 Justices Harlan and Goldberg do not, however, decide what rights are protected by the due process clause of the fourteenth amendment in the same way. Mr. Justice Harlan uses an outright substantive due process test-whether the right is "implicit in the concept of ordered liberty," 381 U.S. at 500; see Palko v. Connecticut, 302 U.S. 319 , 325 (1937). Under that test the provisions of the Bill of Rights do not in themselves define due process; that term may include rights not mentioned in the Bill of Rights but exclude others that are. For Mr. Justice Goldberg, due process includes some, but not all, of the specific guarantees of the Bill of Rights that have been absorbed into the fourteenth amendment, Pointer v. Texas, 380 U.S. 400, 410 (1964) (Goldberg, J., concurring), as well as some rights not enumerated in the Bill of Rights. 
If, as I should surely hope, the law before us does not reflect the standards of the people of Connecticut, the people of Connecticut can freely exercise their true Ninth and Tenth Amendment rights to persuade their elected representatives to repeal it. ${ }^{85}$

Arguments over whether a particular right such as the one involved in Griswold should be vindicated in the courts or in the legislatures will surely be heard again. Yet it is important to bear in mind that state legislatures, in the rightful exercise of their police power, appear to have considerable leeway in enacting laws that seemingly impinge on individual rights. ${ }^{86}$ Where one draws the dividing line between experimentation by a state government in the rightful exercise of its police powers and unconstitutional infringement of individual rights in the course of that experimentation is not yet clear. And if the rights guaranteed in the Bill of Rights are to be protected from state legislative infringement, then what effect can be given to the ninth amendment and its undefined reference to "other" rights? If the existence of such rights is admitted, then how are they to be found, and what standard is to be applied in determining whether they are inherent?

\section{Conclusion}

The ninth amendment should be permitted to occupy its rightful place in the Constitution as a reminder at the end of the Bill of Rights that there exist rights other than those set out in the first eight amendments. It was intended to preserve the underlying theory of the Constitutional Convention that individual rights exist independently of government, and to negate the Federalist argument that the enumeration of certain rights would imply the forfeiture of all others. The ninth is simply a rule of construction, applicable to the entire constitution.

Mr. Justice Goldberg in Griswold v. Connecticut accepted the conclusion that the ninth is only a guidepost pointing to other rights, and not a source or summary of those rights. His opinion looked to other provisions of the Constitution to protect the right of marital privacy, recognizing that the ninth cannot be used as a tool to vindicate this

85381 U.S. at 531.

86 See, e.g., Mr. Justice Brandeis' dissenting opinion in New State Ice Co. v. Liebmann, 285 U.S. 262, 311 (1932) and Justice Douglas' dissenting opinion in Poe v. Ullman, 367 U.S. 497, 517-18 (1961). Whether those cases, dealing primarily with economic rights, are analogous to cases dealing with non-economic personal liberties is a question that deserves consideration. 
right. The due process clauses of the fifth and fourteenth amendments will continue to perform this function, at least for the foreseeable future. ${ }^{87}$ Mr. Justice Goldberg's inability to show that marital privacy is an inherent right that should be protected under the aegis of due process and the obscurity of the process of discovering "inherent" rights are issues for which Mr. Justice Black's caustic remarks may be only opening salvos and Griswold only a preliminary skirmish. The ninth amendment, however, should not provide the battleground on which these issues are resolved.

87 See Rogge, Unenumerated Rights, 47 CALIF. L. REv. 787, 827 (1959); Dunbar, James Madison and the Ninth Amendment, 42 VA. L. REv. 627, 640 (1956). 